University of Nebraska - Lincoln

DigitalCommons@University of Nebraska - Lincoln

The Nebraska Educator: A Student-Led Journal Department of Teaching, Learning and Teacher

Education

$10-2021$

\title{
Diversifying the Classroom: Masculinity and Intersectionality in (Teacher) Education: A Review of Literature
}

Scott V. Gealy

University of Nebraska - Lincoln, scott.gealy@huskers.unl.edu

Follow this and additional works at: https://digitalcommons.unl.edu/nebeducator

Part of the Higher Education and Teaching Commons, and the Secondary Education and Teaching Commons

Gealy, Scott V., "Diversifying the Classroom: Masculinity and Intersectionality in (Teacher) Education: A Review of Literature" (2021). The Nebraska Educator: A Student-Led Journal. 56.

https://digitalcommons.unl.edu/nebeducator/56

This Article is brought to you for free and open access by the Department of Teaching, Learning and Teacher Education at DigitalCommons@University of Nebraska - Lincoln. It has been accepted for inclusion in The Nebraska Educator: A Student-Led Journal by an authorized administrator of DigitalCommons@University of Nebraska - Lincoln. 


\title{
Diversifying the Classroom: Masculinity and Intersectionality in (Teacher) Education A Review of Literature
}

\author{
Scott Gealy \\ Department of Teaching, Learning, and Teacher Education \\ University of Nebraska-Lincoln
}

\begin{abstract}
While much has been written about the gender and demographic divide in the U.S. between the population of students and their teachers, complex gendered, cultural, and socioeconomic forces appear to be widening it. In an effort to reveal the many ways that teacher education programs can attract and retain a more diverse body of candidates, this literature review lays out a general overview of masculinity's work as it pertains to the socialization of boys and young men in K-12 schools; it examines the influence of gendered, racial, and socio-economic assumptions on both teachers and learners; it looks at the experience of men from a variety of backgrounds in teacher education programs and the obstacles to their attraction and retention; and it looks at what the research says about how teacher education programs can be adapted to better account for the intersection of racial, gendered, and socioeconomic identities. Ultimately, the literature suggests work to be done to disrupt gendered, racial, and cultural assumptions about teacher identity that lead to blind spots in teacher education in hopes of better understanding the sources of and finally bridging the gender and demographic divide.
\end{abstract}

Keywords: Masculinity, intersectionality, teaching, teacher education, demographic imperative, gender divide 
THE NEBRASKA EDUCATOR, VOLUME 6

\section{The Gender and Demographic Divides in K-12 Education}

As it has for decades, the population of K-12 teachers in the United States consists primarily of White, middle-class women (Snyder, 1993; Villegas \& Irvine, 2010), a limited demographic that does not align with the population of public-school students, the majority of whom come from diverse racial, cultural, and socioeconomic backgrounds (Snyder, 1993; U.S. Department of Education, 2021). This divide contributes to the disenfranchisement of a large portion of the student population who may not experience teachers who "look like them" (Stillman, et al., 2019) and to boys and young men who may come to equate education with femininity (Connell, 2005; Pascoe, 2007; Young, 2007; Kimmel, 2008; Kivel, 2009). Despite years of measures taken to address them, these gender and cultural divides between the student and teaching populations remain glaring (Ingersoll et al., pp. 12, 15).

The implications of the gender divide in education are significant. Such divisions, argue Johnson, Porter, and Nelsen (2008), "go against the democratic and egalitarian values schools are expected to promote" (p. 3). So long as these divisions persist and students grow up believing they are natural, they will "continue to feed a preponderance of women into teaching and men into administrative or managerial positions, reinforcing the powerfully corrupt idea that men rule women and women rule children" (p. 3). The perpetuation of this binary is a core obstacle to complicating American culture's historically reductive understanding of gender identity.

R.W. Connell, a formative figure in masculinity studies, notes that society communicates and perpetuates an "essentialist" view of gender. This view, as Connell (2005) explains, communicates that "boys and girls are naturally different, in character as well as in body" (2005, pp. 11-12). These differences are used to justify what Connell calls hegemonic masculinities: "the configuration of gender practice which embodies the [...] legitimacy of patriarchy, [and] 


\section{THE NEBRASKA EDUCATOR, VOLUME 6}

guarantees $[\ldots]$ the dominant position of men and the subordination of women" $(2005, \mathrm{p} .77)$.

Schools, explain Eckert and McConnell-Ginet (2013), are "prime sites for socialization," and as such, are "key institutions for the construction of gender" (p. 31).

Indeed, compulsory education is a crucible for identity construction. Pascoe (2007), too, makes clear that "schools are a primary institution for identity formation, development, and solidification for contemporary American youth," (p. 18) and the social construction of gendered behavior is central to this. Quoting Griffin and Lees (1997), Heinrich (2012) describes how “different forms of masculinity are 'performed, contested, negotiated, and resisted in a variety of educational contexts by boys, girls, teachers, and parents"' (p. 105). Pascoe (2007) illustrates these high stakes: "men or boys who do not conform to normative understandings of masculinity and sexuality [are] mocked, humiliated and possibly feared" (p. 90). As in Pascoe's (2007) study, the young men in Heinrich's study (2012) spoke continuously of fear that if they did not prove themselves as sufficiently masculine, they would face persistent and cutting ridicule. Both Pascoe's (2007) and Heinrich's (2012) participants repeatedly called one another 'gay,' an epithet used to imply that one does not measure up or is showing weakness, and therefore not appropriately masculine. Even among boys in school who find themselves well within the margins of mainstream masculinity, there exists a pervasive climate of fear.

The performance — and policing — of gender follows us well into adulthood, and the way teachers unconsciously interact with students is impacted significantly by their gender identity, since "we perform gender in the minutest acts" say Penelope Eckert and Sally McConnell-Ginet (2013, p. 44), "from gait to body language to vocal cadence" (Eckert \& McConnell-Ginet, 2013, p. 44). Teachers contribute to this socialization through gender-based signals of what is appropriate communication for boys and what is appropriate for girls. Though "it is by virtue of 


\section{THE NEBRASKA EDUCATOR, VOLUME 6}

the accumulation of these performances that the gender order is maintained, it is by the virtue of small changes in these performances that the gender order can be restructured" (Eckert and McConnell-Ginet, 2013, p. 44). The messages sent as a result are internalized and reproduced by students, so it is important for teachers to be cognizant of the messages they send. As Connell (2005) explains, "address[ing] the diversity of masculinities, and the intersection of gender with race, class and nationality," will enable society to end the "sterile choice between celebration and negation of masculinity in general" (p. 238). Beyond simply hiring more men to teach, educators must consider the ways in which teachers model gendered behavior in the classroom.

Of course, teachers' and students' identities are shaped by myriad factors beyond gender. It is crucial to consider the role of intersectionality, a term Kimberlé Crenshaw (1991) coined to help account for the ways in which race and gender overlap to represent the multiple forms of identity construction (p. 1245). Following Crenshaw's intersectional examination of the ways in which both race and gender contribute to the oppression of African American women, Patricia Hill Collins (2015) argues that multiple factors contribute to cultural power structures, a matrix made up of "race, class, gender, sexuality, ethnicity, nation, ability, and age [that] operate not as unitary, mutually exclusive entities, but as reciprocally constructing phenomena that in turn shape complex social inequities." (p. 2) These hierarchies of power are both established and fortified in our schools at the expense of the most vulnerable communities.

Shifting the teaching population to match that of students can play a significant role in addressing long-standing structural inequalities that continue to threaten our democracy (Philip, et al., 2019). When students of color do not encounter teachers who look like them, they “implicitly learn that White people are better suited than people of color to hold positions of authority in society" (Philip et al., 2019, p. 285). This logic persists beyond race, however, to 


\section{THE NEBRASKA EDUCATOR, VOLUME 6}

gender, gender identity, ethnicity, socio-economic class, religion, and ability. When students repeatedly encounter teachers who don't look like them, think like them, or interact like they do, the implicit message is that only other people are supposed to teach.

\section{Masculinity in Teaching and Learning}

A man who teaches and is aware of the conventional ways in which our society acculturates gender could help to liberate boys from the oppression of what Kivel (2009) calls the "man box." Men as teachers presenting a more complex and nuanced gender identity in a classroom space where alternate gender expressions are welcomed could be a powerful force for disrupting hegemonic masculinity. Indeed, students' default view of gender as a monolithic category could be disrupted by teaching, both explicitly and implicitly, the myth of the gender binary, and when young people begin to recognize their own place "within dominant discourses of masculinity or femininity, they can begin to understand how this positioning has restricted their own gendered identity" (Heinrich, 2013, p. 105). Abelson (2019) suggests such "changes in style" (gendered behavior in the classroom, for example) could foment real change, but "it takes much deeper collective work of structural relations to make changes in social relations a reality" (p. 205). Since classrooms are among the "specific spaces and places where power relations are created and recreated" (Abelson, 2019, p. 206), perhaps a broad enough shift in the diversity of teachers' identities could lead them to become important social spaces for expanding students' acceptance of the spectrum of gender identity.

Many scholars argue that the presence of a man at the head of the classroom serves as a valuable role model for boys and young men who may rarely see their gender represented by their teachers, but arguments vary on the direct impact of gender on instructional outcomes. Hammerness and Reininger (2008) point to research indicating that same-gendered teachers 


\section{THE NEBRASKA EDUCATOR, VOLUME 6}

“comprise a notable 'environmental influence' on student performance” (p. 3). Dee's (2005, 2007) work notes that "gender interactions" between teacher and student "constitute [a] qualitatively important environmental determinant of the comparative outcomes of both girls and boys" (p. 551), but Johnson, Porter, and Nelson (2008) disagree, asserting that "adequate empirical evidence does not exist that supports matching students and teachers by gender [...] has any effect on a variety of student achievement and satisfaction measures" (p. 3). It is reasonable to assume, therefore, that this single factor cannot reliably account for the complex connection between a teacher's identity and a student's performance.

In fact, on its own, the view that a man who teaches is by nature a role model for boys and young men is regularly seen as overly simplistic. Davison and Nelson (2011) point to the "messiness" of identities in the classroom, "not as something that needs to be sorted, solved, or fixed in a prescriptive way, but as a complex concern for educators and the children and families they teach" (p. 95). Much of this "messiness" results from tension surrounding descriptions of what it means to be a man, an educator, and role model, particularly in the face of "conflict and tension regarding popular understanding of masculinity and a reliance on narrow gender expectations for boys and young men" (Davison and Nelson, 2011, p. 93). The reality is that being a boy or a man should not be easily described; so to assume that the latter will be a role model for the former strictly because of this single factor is misguided.

Gosse (2011) follows Davison and Nelson (2011) to weigh in on the debate over the value of men who teach in the primary grades. Gosse's research shows the issue falling into two camps: those who believe that any child can succeed in a classroom lead by any teacher, regardless of gender, race, or ethnicity, and the one to which Gosse subscribes, where men contribute as role models, an important factor for establishing "a gender balance, along with 


\section{THE NEBRASKA EDUCATOR, VOLUME 6}

other identity markers, in order to better represent and reflect diversity in education" (p. 119). Here we see the "messiness" described by Davison and Nelson (2011). One can reasonably see the value of a variety of identity markers in the conglomeration of leaders experienced by students in a classroom.

Regardless of the correlation between teachers' gender and student performance, there is little doubt that a teacher's performance of gender contributes to students' understanding of appropriately gendered behavior. Johnson, Porter, and Nelson (2008) argue that there needs to be an increase in men who teach, but not simply as role models to improve student outcomes or the disruption of conventional gender roles (pp. 2-3). Instead, they argue that "an overwhelming majority of women $[\ldots]$ in an entire social institution violates fundamental democratic principles of equal opportunity, access, and self-determination based on gender in a free and open society" (p. 3). "It is possible," they argue, "that restrictive gender roles limit equal opportunity by discouraging men from teaching who might otherwise be predisposed" (p. 3), while tacitly communicating that girls and young women are best suited to teach.

A number of studies push for but question the motivation to increase the number of men in the classroom. Skelton (2007) argues that government programs meant to increase the number of men who teach in public schools are problematic without a more robust focus on gender issues in teacher education programs. Francis (2008), too, challenges the motives. The push for male teachers as role models, often for disaffected boys, is grounded in the assumption that men teach students differently than women, since "arguments for the desirability of male [...] teachers of boys rests on stereotypes of male teachers as disciplinarian and 'robust"' (Francis, 2008, p. 109). These notions assume that gender identity is "foundational and fixed," built on the assumed binary of gendered behavior (Francis, 2008, p. 119). In reality, the role of men who teach is 
THE NEBRASKA EDUCATOR, VOLUME 6

described by Francis (2008) as a form of heteroglossia, "whereby 'competing dialects of masculinity and sexuality engage each other in a single text," which cannot be easily discerned by gender alone (p. 120). The three cases in Francis's study illustrate "the complex, shifting and nebulous nature of gendered subjectivity," identities "riven with contradictions and fluidity," and that "masculinity and femininity are not the exclusive provinces of 'appropriately' sexed bodies" (2008, p. 120). Mills (2004) argues that initiatives aimed at diversifying the teaching profession by attracting and retaining more men "only recognizes diversity between males and females and does not give any indication that it recognizes diversity among males and females" (p. 31). According to these scholars, increasing the number of male teachers does not provide real diversity. Rather, it reinforces gender binaries as the status quo, marginalizing, particularly, LGBTQ+ students who continue to face an environment in schools where the "heterosexual-us" and the "homosexual-them" paradigm continues to thrive (p. 34).

This gender duality is apparent in Haase's (2008) study, which demonstrates that many male teachers see it as their duty to socialize boys to a single standard that proves their strengths and viabilities as young men. Moreover, these men appear to compensate for their role in a largely "feminized" teaching environment by using their masculinity to serve a need for boys that only they can, according to common sentiment, thus reinforcing gender normativity (Haase, 2008, p. 115). This aligns with Britzman's (2003) assertion that "male teachers are expected to assert a machismo identity in their classrooms, and depending upon their proximity to this image, become characterized either as wimps or tough guys" (p. 29). Fischman (2000) asserts that without significant efforts to redefine gender regimes in schools, future teachers will have "few opportunities of transforming resistance into agency and break [...] with the essentialist view of caring as a feminine activity and 'discipline' as the exclusive realm of men” (p. 164). Haase 


\section{THE NEBRASKA EDUCATOR, VOLUME 6}

(2008) synthesizes these points by arguing that expanding not only the number of male educators, but the variety of individuals asserting identities of 'manhood' becomes crucial for disrupting hegemonic gender binaries. "Unless [...] strategies designed to attract more male teachers by sophisticated understandings of gender and social power [are put in place], masculine stereotypes will simply be passed down" (Hasse, 2008, p. 115). Thus, it is not just the number of men attracted to the profession, but the type of men that may disrupt norms of gender identity construction in the classroom.

Martino and Rezai-Rashti (2010) draw on feminist, queer, and postcolonial theoretical frameworks to examine the complexity of gender dynamics in teachers' lives as they intersect with race, social class, and sexuality. Their work follows other studies that problematize the reductionist notion of teachers as "idealized role models," which fails to acknowledge "the damaging effects of reducing the formation of gender identity to the category of sex-role stereotyping" (p. 250). The authors take an intersectional approach to "move beyond singularity" of the heteronormative binary, "taking into account the reality that each of us embodies a wide range of categorical commitments such as race, sexuality, generation, [and] class" to more accurately capture the ways in which "the shifting meanings of these social markers arrange the experience of gender" (Rezai-Rashti, 2010, p. 251). Ultimately, these arguments further complicate the assumption that simply increasing the number of men who teach will disrupt conventional gender norms.

Embedded in the discussion but less often raised in the research is the way a teacher's gender is read by their students. “A teaching body,” argues Waite (2017), “will always be waited for, looked at, put on its front-of-the room stage as the first kind of student knowledge, the first body of knowledge" (p. 23). The gendered traits of what we look like and how we communicate 


\section{THE NEBRASKA EDUCATOR, VOLUME 6}

are fundamental markers of our gendered teacher identity, though many White, cisgender teachers likely do not pause to consider the implications.

Braun's (2011) work explores the physical and psychic embodiment of pre-service teachers as they make the transition into a full-time teaching role. The study consists of a series of qualitatively analyzed interviews with post-graduate teachers in training. The emphasis in the findings is very much on the physical embodiment of the teaching persona - the way in which student teachers feel as if they need to inhabit a certain kind of physical body in order to generate authority in the classroom. Braun examines findings under two categories: "the appropriately gendered body, signified by heteronormative readings of gender and sexuality; and the gendered authoritative body, conceptualized as male" (2011, p. 127). Ultimately, Braun (2011) argues for embodied considerations as part of teacher training programs, since such notions are the reality of teachers' lived experience in the classroom.

Sarah Bortolome's (2016) narrative study sought "to explore the experiences of a [maleto-female] transgender music educator as she navigated her teacher preparation program and entered the field" while in the process of deciding how to present, as Matthew, Mel, or Melanie. How does one embody the teacher when one's body itself has the potential to disrupt the classroom? In addition to the commonplace preservice teacher's insecurities, Melanie was forced to ask herself, "Are the kids going to realize that I am a 'gender imposter'?” (p. 36) Ultimately, according to Bortolome, the students appeared to take little notice. Melanie's narrative provides evidence that relatively seamless dismantling of the reductionistic gender binary of the classroom teacher is possible, at least in certain contexts. Nevertheless, addressing in teacher education the effects of a teacher's gender identity performance on the subtle messages sent to students should be an important component of teacher education. 
THE NEBRASKA EDUCATOR, VOLUME 6

\section{Consequences in the Classroom}

Increasing the number and diversity of men who teach could complicate the too often rigid definition, both in schools and in broader society, of what it means to 'act like a man' (Kivel, 2009). As Johnson and Weber (2011) argue, "a man who is passionate about teaching often belies the gender codes that constitute mainstream masculinity" (p. 154). As the scholarship makes clear, however, increasing the number of male teachers is not enough. Traditional socialization of gender norms in public schools appears to leave little room for boys and young men to deviate from acceptably masculine behavior. Hiding emotions, being aggressive, not backing down, and toughening up all become the enforced norm (Kivel, 2009). An increase in the number and variety of men who teach, particularly in the humanities, could help to establish new norms for appropriately masculine behavior.

Being a good student is one of the behaviors that is often strictly policed among boys and young men. As Dowd (2010) argues, "to be viewed as sufficiently masculine, boys must not be seen as working too hard at schoolwork, so boys are not 'free' simply to achieve at school without great social cost" (p. 79). The internalization of this message has long term consequences for achievement among untold many young men. This is particularly true in an English context. Heinrich's (2012) study “revealed the English classroom as a politicized and gendered arena" (p. 112) where being productively engaged was, for boys, to be stepping out of acceptable behavior. To stand out for being studious conveys the appearance of being 'weak' or 'feminine,' and thus is both implicitly and explicitly discouraged.

Research conducted by Martino (2001) in the 1990s demonstrated that English as a subject is seen as more feminine than other subjects. The result was that "boys were caught up in a gender bind in which they perceived [...] English as a feminized learning practice that 


\section{THE NEBRASKA EDUCATOR, VOLUME 6}

conflicted with their tenuous masculinity" (p. 193). The boys in Martino's (2001) study found reading "boring," so they chose not to engage with learning that they felt did not "validate a form of masculinity that they find desirable" (p. 193). A significant body of scholarship confirms Martino's (2001) observations. Smith and Wilhelm (2002) argue that literature and language tend to focus on "narrative, emotional response, expressivity, and creativity," instead of more hands-on learning or action-oriented texts, but, perhaps most importantly, "[English classes] are most often taught by females, [which] deprives boys of male models who embrace the life of the mind, the emotions, and the various forms of literate creativity" (p. 16). Again, though, these assumptions appear reductionistic.

Dowd (2010) refers to a "boy crisis," resulting from a sort of zero-sum-game where boys are falling further behind because the system is somehow failing them, and that this failure is a price being paid for girls' and women's progress in schools (p. 76). This argument, advanced by Farrell and Gray (2018), was predated by nearly 50 years by Patricia Cayo Sexton in The Feminized Male (1969). But this view, like many, is generalized and reductive. As Kimmel (1998) argues, "it is not the school experience that 'feminizes' boys, but rather the ideology of traditional masculinity that keeps boys from wanting to succeed. Boys see academic success itself as a disconfirmation of their masculinity" (p. 294). Heinrich's (2012) study exemplifies Kimmel's contention, illustrating that it is the fear of ridicule, "not apathy or stupidity as teachers sometimes assume," that suppresses boys' willing participation in class, "for the process of finding voice was a high-stakes one, laden with considerable risk and consequence" (pp. 110111). Men who appear to students as 'sufficiently masculine,' yet model passion for literature and creative expression could resonate with boys in ways that give them the comfort and confidence to risk being socially vulnerable in the classroom. 


\section{THE NEBRASKA EDUCATOR, VOLUME 6}

The feeling of disconnection from school appears to correlate with concerning patterns in motivation and achievement as students transition from high school to college. For boys and young men, performance of masculinity often erodes membership in the academic community. In order to re-establish academic success among boys, Mintz (2019) argues, there are a number of issues that need to be addressed, both cognitive and behavioral. Boys and young men tend to be academically underprepared for a variety of reasons, many of them related to behavioral tendencies, learning style, and cognitive function; in the last twenty years, boys have undergone consistent decline in academic aspirations, and schools have become increasingly unresponsive to the differing needs of students. As Kahn, Brett, and Holmes (2011) discovered in their study of the connection between masculine norms and achievement in higher education, women entering college are better motivated and better achieving than their male counterparts, which has consequences throughout their ensuing education (p. 66).

Views regarding boys' under-achievement, too, are often generalized, however. Girls tend to do better in language and literacy (the effect of factors listed above), while boys tend to do better in math, and the genders are roughly equal in science, and much of the disadvantage demonstrated by men is linked to class and race, not just gender (Dowd, 2010, p. 77). Thus, looking at equity as a matter of gender alone is problematic, since class and race are far more significant in the differentiation of outcomes in school. Focusing on gender alone can unintentionally distract from other issues that may have a more significant impact (Dowd, 2010, pp. 80-81).

Far more impactful than gender for student performance is social class, a factor typically determined by a combination of family income, occupation(s), and level of education (American Psychological Association, 2015). Lareau's (2011) extensive ethnographic work demonstrates 


\section{THE NEBRASKA EDUCATOR, VOLUME 6}

how social class provides parents a "set of cultural repertoires for managing the experiences of their children as they interact with institutions such as schools" (p. 265). In fact, Lareau's work demonstrated that much of the experience children have in schools is closely tied to their social class. "Middle-class kids tend to go to different, and more academically, socially, and physically desirable schools than do working-class and poor kids" (Lareau, 2011, p. 265), and high schools typically expect parent involvement in bringing about a child's successful navigation of the complicated process of applying to college (Lareau, 2011, p. 265). Parents without the understanding of school's institutional structure and culture or the time to help their students navigate this sophisticated system often leave their children at an insurmountable disadvantage.

Key among the discoveries of Lareau's (2011) work is a classed approach to child rearing. The study identifies two distinct ways in which parents raise children: "concerted cultivation" and "natural growth" (pp. 2-3). The former, deeply associated with middle-class parents, is an approach to parenting emphasizing the development of children to "cultivate [their] talents in a concerted fashion," which typically means that "organized activities, established and controlled by mothers and fathers, dominate the lives of middle-class children" (Lareau, 2011, pp. 1-2). The result is parents providing for their children advantages that will contribute to their educational and professional advancement. Lareau (2011) distinguishes this approach from "natural growth," most frequently practiced by poor and working-class parents, who, in the study, did not consider the manipulation of their children's development through organized activities an important element of good parenting (p. 2). Children of poor and working-class families are often marginalized, since institutions such as schools typically assume that parents are taking an approach of deliberate cultivation. The result, Lareau explains, is that "for workingclass and poor families, the cultural logic of child rearing at home is out of sync with the 


\section{THE NEBRASKA EDUCATOR, VOLUME 6}

standards of institutions" (p. 3). Moreover, Benton (2007) describes how schools in working class neighborhoods sort kids mostly into subservient roles, allowing for a handful to make it out by defying their peers and learning to play by the rules established by the "weeding process and the tracking system" (p. 70). The others, the vast majority in poor and working-class communities, "know that trying too hard at school will cost them friends and make them targets for violence" (p. 70), making academic achievement and social status a seemingly either-or proposition. Thus, children in middle- and upper-middle class families enjoy tremendous longterm educational and professional advantages. Teachers and administrators, often raised in middle-class backgrounds themselves, must understand the cultural advantages and disadvantages children may bring with them to the classroom and adjust their support accordingly.

Dykins Callahan’s (2008) autoethnographic article, “Academic Outings,” chronicles her experiences of learning to hide her family's poverty, doing everything in her power to "pass" as middle class from the tumultuous years of middle school, through high school, into college, graduate school, and an academic career. "Derogatory representations of poor Whites," she argues, "combined with physical, emotional, and educational 'flaws' that individuals acquire because of their class status clearly position members of the lower classes as highly stigmatized" in the academic community (p. 365). The concept of "class passing," Dykins Callahan (2008) explains, means that students have to work harder to reconcile conflicts between their "inherited" identity and their "chosen" identity at school (p. 364). Her life at home would never let her outrun the feeling of being an imposter at school, of not being good enough to truly belong. Even in a university setting, she worked exhaustively to remove traces of her private life from her social and academic persona. "The academy is often considered a classless arena whose 


\section{THE NEBRASKA EDUCATOR, VOLUME 6}

participants exist outside the confines of economic categories," but this "myth of classlessness only perpetuates the invisibility of the working poor who limp through the hallowed halls" (Dykins Callahan, 2008, p. 369). Her paralyzing fear of being recognized as inferior haunted her from her earliest years in school through a career in academia. Benton (2007) elaborates on issues underlying class discrimination and prejudice on college campuses based on his experiences both as a student and a faculty member, arguing that, "academe's admissions, hiring, and the promotion practices seem to favor people who look different but mostly think alike, largely because they belong to similar class strata," which leads to "making privileged people feel like they care about inequality without having to really change anything” (p. 70). Social class, "nearly a caste system" (Benton, 2007, p. 70), must be included in any consideration of diversity, though he laments the fact that it does not. The world of the academe must acknowledge the complexities of the impact social class has on the experience of the students (Dykins Callahan, 2008, p. 371). Understanding this impact on students adds a crucial layer to the effect of gender, sexuality, race, and culture on power dynamics in the classroom. "Focus[ing] on the axes of these [intersectional] positionalities, their co-constitution [and] permeability, as well as how they are negotiated in specific contexts" (Dykins Callahan, 2008, p. 371) is crucial for providing a safe space for students from diverse poor and working-class backgrounds.

The interplay between poverty, race, and education is particularly complex. Increasing the number of teachers of color, as Villegas, Strom, and Lucas (2012) argue, "decreases the sense of alienation that students of color — from both poor and affluent backgrounds — often experience in schools" (p. 285). Young (2007) digs deeply into the complicated intersection of race, poverty, gender, and education that exists in much of the African American community. 


\section{THE NEBRASKA EDUCATOR, VOLUME 6}

Success in school, Young points out, is often equated with "acting White," a behavior that many African American boys and men are particularly resistant to, since to act White means not only selling out your Black identity, but adopting what are typically seen as feminine traits. As a Black academic whose roots are in urban poverty, Young is caught between cultures; he is "required to perform [his] academic (read white) and ghetto (read black) languages in order to quell and fulfill the racial, class, and gender fantasies that others have of [him]" (2007, p. 3). African American men who succeed in academic environments "must often contend with being perceived as unmanly [...] [and] being deemed inadequately masculine is tantamount to being judged homosexual" (2007, p. 65). For Young, the culture of the Black man and the culture of school existed almost in binary opposition and, as a career academic, he felt accepted by neither his home community nor the academy.

The complexity of the human experience one encounters in the classroom is best served by a varied and reflective teaching body. While academic success is in many ways impacted by gender, unraveling that component from the intersectional experience of students who struggle to find their place extends far beyond that single factor. According to Mintz (2019), "the challenge for teachers is to develop the abilities of all students as fully as possible. This requires attentiveness to classroom dynamics, including gender dynamics, responsiveness to students' needs, and the ability to differentiate instruction" (para. 18). In order to address the gender divide and the demographic imperative to make inroads with students the system has traditionally left behind, educators must consider the totality of human experience in our understanding of who becomes a teacher, how, and to what end. 
THE NEBRASKA EDUCATOR, VOLUME 6

\section{Multiplying Identities in Teacher Education}

As Britzman (2003) explains, too often images of teachers have little to do with individual behavior, but instead are grounded in an "adherence to patriarchal conventions, notions of a unitary non-contradictory identity, and images of professionalism that preclude the struggles of gender class, race, and generation.” Instead, as human beings, teachers' identities are "multiple... both given and possible," but too often become lost in a cycle of "cultural determinism" (Britzman, 2003, p. 29) where images of the teacher are one-dimensional. This contributes to Stillman et al.’s (2019) findings, that “teacher education programs have been shown to privilege the experience of White preservice teachers [and] undervalue the knowledges and experiences of minoritized communities" (2019, p. 266). Zeichner (2020) makes the more definitive claim that "most teacher education programs, including those that have claimed to be about social justice," too often contribute to the disenfranchisement of poor communities and communities of color by training teachers "who have not benefited from the knowledge and expertise that exists within their students' families and communities" (p. 42).

To overcome this, teacher education programs must work toward what Stillman et al. (2019) call asset-oriented teacher education, "committed to the preparation of asset-oriented teachers, who recognize, leverage, and sustain the knowledge, values, and voices of minoritized students" (p. 266). While care must be taken to avoid what Lowenstein (2009) calls the “homogenization lens," through which the often complex backgrounds within a seemingly unidimensional demographic (White and largely female, in this case) can be overlooked (p. 168), further diversifying the preservice teaching population is the surest way to provide depth to the classroom experience, both in teacher education programs and K-12 schools. 


\section{THE NEBRASKA EDUCATOR, VOLUME 6}

In addition to gender-based stereotypes, superficial understanding of teachers' identities and backgrounds have led to African American men frequently being valued in K-12 classrooms for their ability to "save" troubled African American boys (Strachan and Davis, 2020, p. 69). This reductive understanding makes urgent the need for the stories of African American male educators in order to better understand why they chose the field and the experiences that got them there. Such stories would serve as an effective vehicle "to examine how the pathway to K12 classrooms [for men of color] can be improved" (p. 69) and help to transcend superficial understandings of who teaches and why. Much blame for this simplistic understanding, however, lies at the feet of traditionally culturally homogeneous teacher education programs (Lowenstein, 2009; Villegas, 2008).

Tucker (2015) looks at the experiences of men in teacher education programs through the lens of "hybridity," citing Moss (2003) who defines the term as the "the joining of two entities to create a third $[\ldots]$ produced by the interaction of cultures, communities, or individuals"' (p. 6). The study investigates "how male preservice elementary school teachers negotiate different aspects of their identities as they navigate their educational experiences" (Tucker, 2015, pp. 6-7). Their findings suggest that preservice male teachers' identities are more complex than gender alone, that "being in multiple minority groups may compound challenges for preservice male teachers, and that teacher training alone may not sufficiently address issues of identity" (Tucker, 2015, p. 3).

Research by Bower-Phipps et al. (2013) indicates that minority teacher candidates often feel disconnected from teacher education, since "the voices of underrepresented teacher candidates are missing from the curricula, the classroom, and the literature" (p. 32). Overall, students who identified as "other" felt they faced different expectations from those set for White, 


\section{THE NEBRASKA EDUCATOR, VOLUME 6}

women teacher candidates," which "generated feelings of insecurity" (p. 32). Overall, the participants "faced the challenges of isolation; lack of background knowledge; different, often lower, expectations from cooperating teachers" (Bower-Phipps, 2013, p. 38). The prevalence of such experiences can do nothing but further widen the demographic and gender divide among teachers in this country.

The experience of being "othered" is common among Black men in teacher education programs. Warren's (2013) autoethnography describes his experience as a Black man in one such program. In his predominantly White elementary education cohort, he quickly found himself in the position of other. Warren began his program as the single Black man "among what seemed to be a sea of White female preservice teachers" (p. 170). Most of his classmates were from suburban and rural areas, and "most flaunted [their] privileged upbringings" (Warren, 2013, p. 170). He felt the strong presence of intimidation in his peers, many of whom had never interacted with a person of color, "let alone a Black man" (p. 171). He felt alone and misunderstood, and often felt the need to challenge the assertions made by peers he saw as naïve or misguided when it came to understanding people who were different from them. Sadly, Warren's story "is one of many that exist among an isolated cohort of Black males persisting in an increasingly White and female-dominated profession" (2013, p. 169). Jones (2011), however, concludes through his study of three African American men in a graduate teacher education program that the idea that all experiences of African American students in teacher education programs are the same is misguided (p. 115). There were a number of common experiences, however, including the persistence of microaggressions and the ways in which students of color are perceived, manners in which the participants avoided race and racism "as a permeating force" in their graduate teacher education program, and the burden of having to "live up to" the role of racial 


\section{THE NEBRASKA EDUCATOR, VOLUME 6}

"spokesperson" in a predominantly White cohort with predominantly White professors or to "live down to" societal expectations (Jones, 2011, p. 114).

While efforts to recruit and retain more male teachers is extremely valuable, it is crucial that such teachers embody a wide range of gender and cultural identities in order to match the broad spectrum of socio-cultural experiences of the students they will teach. The more we diversify the teaching force and narrow the gap between students' and teachers' lived experience, the more likely we will be to disrupt culturally homogeneous and binarily-gendered notions of what teacher education programs feel like and what good teaching looks like.

\section{The Challenge of Attracting and Retaining a Diverse Teaching Force}

Teacher education programs that often struggle to attract and retain men and students from culturally diverse backgrounds are tasked with addressing both the gender divide and the "demographic imperative" (Villegas, 2009) to better align the multiple identities of teachers with those of their students. This has proven to be a tremendous challenge, however, since as recently as 2017, women earned more than 80 percent of degrees in education (Perry, 2019, online chart), and students of color have far lower college attendance rates, tend to enroll in teacher education programs in relatively small numbers, and score far lower on licensure exams than their White counterparts (Ahmad and Boser, 2014, pp. 11-13). As a result, teacher preparation programs continue to struggle to provide an intersectionally diverse pool of applicants to K-12 schools (Hammerness and Reininger, 2008).

The research makes clear several factors that contribute to the limited enrollment of men and those of diverse cultural backgrounds in teacher education programs, including those grounded in socioeconomic, racial, and cultural biases in education. One factor that seems to cut across the cultural spectrum is the role of hegemonic masculinities (Connell, 2005, p. 77), which 


\section{THE NEBRASKA EDUCATOR, VOLUME 6}

tend to pressure men into the need to avoid "anything feminine in pursuit of achievement of status, independence and self-confidence (p. 4). Such socialization, the preponderance of research shows, has led men away from teaching, which enjoys relatively low professional status (Dolton et al., 2018, p. 18) and is often associated with femininity (Monticenos and Nielsen, 2004). This characterization has faced much criticism, however, for its reductionistic perpetuation of masculinity as a "unitary concept," instead of one that is constantly evolving (Monticenos and Nielsen, 2004, p. 4).

Much of the literature citing obstacles to the attraction and retention of men focuses on elementary education, since the gulf between men and women teachers is less severe in secondary education (64\% to $36 \%$ ) than elementary (89\% to $11 \%$ ) (National Center for Education Statistics, 2021, Figure 1). It must be noted, however, that in secondary education, these percentages are deceiving, since they can be further disaggregated by subject. For example, according to the Brown Center Report on American Education (2018), 54 percent of secondary social studies teachers were male, compared to only 20 percent of English/language arts teachers (Hansen et al., 2018, Figure 1), further indicating the need for more men from diverse backgrounds in arts and humanities classrooms, which continue to be stigmatized as feminine (Martino, 2001; Smith and Wilhelm, 2002; Martino, 2010; Heinrich, 2020).

Shortages of men who teach, particularly in elementary education, can be traced to common stereotypes about teacher education programs. Weaver-Hightower's (2011) work pointed to the perceived ease of teacher education courses. One participant lamented the fact that he couldn't just learn the material and be tested over it, instead having to "“draw little balloons around all my [...] projects" (p. 105). Project-based learning is something commonly associated with femininity, and many students feel such an approach doesn't provide the "rigor" of other 


\section{THE NEBRASKA EDUCATOR, VOLUME 6}

programs (Weaver-Hightower, 2011, p. 105). The implicit message is that smart and talented men can do something more important.

The messages received by the young men in Weaver-Hightower's (2011) study came primarily from male peers and elders. Many of their fathers tried to dissuade them from teaching, instead encouraging them to pursue work with higher pay and higher status. This supports Kimmel's (2008) findings that "guys hear the voices of the men in their lives-fathers, coaches, brothers, grandfathers, uncles, priests - to inform their ideas of masculinity" (p. 55). The message to many young men was that "only the unsuccessful [...] should teach." (WeaverHightower, 2011, p. 107), a message heavily laden with the link between financial and professional success, since "an intelligent, capable male maximizes his earning and status potential" (p. 108). Many of the participants in Monticenos and Nielsen's (2004) study acknowledged the evolution of gender roles, noting that women are "becoming stronger" while "men are being portrayed now as the sensitive man" (p. 6), which allowed them to feel more at home in elementary education than they may have in the past. As encouraging as this shift seems, "adopting this new cultural image of manhood came with warnings and resistance from family members" (Monticenos and Nielsen, 2004, p. 6). While young men's perception may be that the culture is shifting, pressure remains to adhere to traditional and confining roles of masculinity.

Another pervasive fear of men in education is that their actions will be "misperceived as sexual, whether homosexual or pedophilic" (Weaver-Hightower, 2011, pp. 108-109). Men in the classroom often worry that they are assumed to be "sexual initiators, or worse, [even] aggressors" (Weaver-Hightower, 2011, p. 109). In this vein, Everitt (2018) describes the ways such programs reinforce gender conformity by articulating a clear dress code, particularly for 


\section{THE NEBRASKA EDUCATOR, VOLUME 6}

women. Appropriate women's dress relies on the assumption that "boys will be boys" and that if female teachers dress provocatively_-"exposed cleavage, bra straps, thongs, midriff, or legs" (p. 64) — they are inviting inappropriate attention and behavior from (male) students. There is a clear gender distinction that reinforces men as subjects and females as objects - men are inherently predatory, and women are inherently vulnerable — which has implications for men who teach.

While teacher professionalism standards for women relied heavily on dress, professional standards for men had much to do with behavior, particularly toward young women. Just as men in elementary education often fight negative stereotypes and suspicions regarding their sexuality and their motives for working with young children, men in secondary education are stigmatized as sexually targeting female students. Many men feel they are "perpetually under scrutiny—if not suspicion—for pursuing sexual relations with minors" (p. 68). Men often possess a fear "rooted in the knowledge that people assume men to be initiators of amorous relationships with women based on rationalized meanings of masculinity" (Kimmel, 1998, p. 69). The result is that men preparing for careers in teaching come to learn that they must subdue such behaviors, but "even abstaining from [them] is often not enough to avoid this kind of scrutiny" so that, "men who work as teachers face constant suspicion" (Kimmel, 1998, p. 69). Thus, both men and women face ambivalence about their gender conformity in the classroom. "While women must $[\ldots]$ cope with the possibility of being sexually objectified [...] men must cope with the possibility of being viewed as sexual predators despite their best efforts to avoid it" (Kimmel, 1998, p. 69). Of course, gender embodiment inherently includes "sexualized meanings," and the construction of a teacher identity assumes the removal of such meanings; "teacher candidates face complex contradictions" (Kimmel, 1998, p. 69) when envisioning who they are and how they behave in the classroom. 


\section{THE NEBRASKA EDUCATOR, VOLUME 6}

The men in Jones' (2008) study were very aware of this culture of suspicion, in which male elementary teachers are viewed as potential pedophiles or sexual predators (p. 127). Johnson, Porter, and Nelson (2008) note that "men experience undue pressure to avoid physical contact $[\ldots]$ for fear of perceived impropriety" (p. 5). The literature suggests that this at least perceived scrutiny causes stress for men who enjoy working with children (p. 5). Montecinos and Nielsen's (2004) work demonstrates that men tend to be leery of the ways in which their actions around young children could be interpreted. Many men noted that "districts' policies and guidelines regarding physical contact between children and adults were enforced differently for men than women" (Montecinos and Nielsen, 2004, p. 6), which led male preservice teachers to be aware that they would have to exercise greater restraint in their emotional expression and demonstration of affection than other educators. This is consistent with the findings of WeaverHightower (2011), who notes that teachers often modify their behavior, becoming less warm or affectionate, to decrease the likelihood of being perceived as sexually deviant (2011, p. 109). Haase (2008) suggests that such modification of behavior "serve[s] to propagate widespread perceptions of male teacher role models as non-nurturing, or less nurturing than female colleagues, and thus less equipped to work with children" (p. 128). This leads to a "heterosexist and rigidly gendered educational system that helps keep [women] in majority status" (Haase, 2008, p. 128) and supports Johnson, Porter, and Nelson's (2008) assertion that “male teachers reinforce rather than challenge the same restrictive gender roles that turn men away from teaching in the first place" (p. 3), since to do otherwise could give rise to suspicion. Interestingly, these constraints tended not to trouble the participants in Montecinos and Nielson's study, however, with many citing "their own proclivities for traditional male 'distance"” (2004, p. 6) a nod, no doubt, to Haase's (2008) and Kimmel's (1998; 2008) notions of gendered socialization. 


\section{THE NEBRASKA EDUCATOR, VOLUME 6}

Sandles (2020) points out that the dearth of Black men who teach contributes to a broader cultural message that African Americans are not as well-suited for positions of authority as Whites. Thus, "it is crucial for all students to observe and interact with capable, qualified Black male teachers in order to deconstruct deficit-oriented paradigms regarding Black men" (p. 71). Among the primary contributors to the shortage is "the centrality of race and racism in society" (Sandles, 2020, p. 71), the product of which continues to be racial segregation and decreased access to quality education and economic opportunities. This leads to fewer men of color with interest in becoming or the skills to become teachers and the tendency for men of color who do teach, "voluntarily or involuntarily [...] to work in environments with concentrations of [B]lack students," which often land them in the most difficult schools (Sandles, 2020, p. 72). Black men who teach in predominantly White schools often become marginalized within largely White communities of educators, particularly if they deviate from conventional forms of instruction that perpetuate the racial status quo (Sandles, 2020, p. 73). Institutional forms of racism such as color-blindness and meritocracy serve to assuage the guilt of Whites while perpetuating racist practices, and thus the quantity of Black men in the classroom (pp. $73-74)$.

Based on their institutions' difficulties attracting and retaining students of color, Miller and Hidehiro (2005) set out to learn about the experiences of education students of color to better understand why they hoped to become teachers. Their work found that the primary factors leading students of color to teaching were having educators in the family, having parental support for teaching as a career, having previous teachers as significant role models, and close bonds with influential teachers (Miller \& Hidehiro, 2005, pp. 6-7). While many of these bonds were with White teachers, participants noted that they need teachers with whom they can “identify culturally, racially, ethnically, and perhaps linguistically" (p. 7). Any number of factors 
THE NEBRASKA EDUCATOR, VOLUME 6

may lead men and traditionally marginalized students to teacher education, but it is clear that increasing teacher diversity will add important role models to students' lives, perhaps leading to a proportionate increase of their representation in the classroom.

As teacher education considers its path forward, it is important to take a critical approach to issues of intersectional diversity, following Creswell and Poth's (2018) assertion that critical theory is grounded in "empowering human beings to transcend the constraints placed on them by race, class, and gender" (p. 29). There is tremendous value for adolescents in escaping typically well-policed behavioral expectations in order to inhabit more liberating social contexts. Teachers have the unusual opportunity to support such empowerment, but just as much ability to stifle it. Teacher education programs must work, not only to attract and retain future educators from a variety of backgrounds, but to instill in them an understanding of the impact a teacher's identity has on their students.

\section{Interventions in Teacher Education Programs}

Beyond working to attract and retain a more diverse preservice force, it is crucial that the process of teacher education be framed by an understanding of gender theory and their implications for social justice. This may be the best way to combat the default to what Mills calls "common sense" approaches to gender (2004, p. 34). Such approaches "are often shaped by conservative reading of contemporary politics and do little to change equity within education" (Mills, 2004, p. 34). Instead of bringing more diverse voices into education, the introduction of more men without the interrogation of gendered behavior and consequences can further entrench misogynistic and homophobic views. Ultimately, "exploring the ways in which homophobia and misogyny construct gendered relations within schools $[\ldots]$ affects all teachers and students" 


\section{THE NEBRASKA EDUCATOR, VOLUME 6}

(Mills, 2004, p. 35) and schools of education should make gender and other forms of social justice core components of their programs.

While Sanders' (2002) article and the statistics she cites are nearly twenty years old, her argument for the examination of both teacher education programs and the construction of new teaching identities seems to be increasing in urgency, since anecdotal observation and a baseline review of the literature indicate that little has changed in teacher education's examination of the impact of gender on the social construct of learning. Sanders' (2002) work comes on the heels of Sommers' The War Against Boys and at roughly the same time as Newkirk's Misreading Masculinities: Boys, Literacy, and Popular Culture (2002) and Smith and Wilhelm's Reading Don't Fix No Chevys (2004), which examine the differences between the ways in which boys interact and perform in the classroom. Sanders cites several studies in the 1990s showing that "gender equity [was] in its infancy in teacher education" (Sanders, 2002, p. 242) and that any focus on gender was sporadic and often tied to "a few committed faculty members" (p. 243). Sanders (2002) argues that attention to gender equity must be systemic, not approached like so many multicultural education courses — a "balkanized [...] sidebar to the 'real' work of education" (2002, p. 243). Despite many attempts at progress, the tokenistic or altogether absent examination of issues related to gender in programs of teacher education continues.

Johnson and Weber (2011) focus on the typical omission of the study of gender, and masculinities in particular. For preservice teachers, they found, complex discussion of nuanced masculinity and gender are often scarce. To Johnson and Weber (2011), "gender, along with other intersectional identities, should always be considered as one of the central lenses through which education research and practice are viewed" (pp. 141-142). Minus the opportunity to 


\section{THE NEBRASKA EDUCATOR, VOLUME 6}

reflect on our own gender construction and its impact on our practice, most preservice and inservice teachers will likely do little to understand or question the implications of the status quo.

Engebretson (2016) sought to better understand how preservice teachers conceptualize gender and gender discourses by following 25 students for a year through their secondary social studies teacher education program. Her findings indicate that it is "imperative that our teachers analyze and deconstruct their complex, personal, and often unshared ideas around gender," (p. 51). Preservice teachers' ability "to make connections between their lives, the lives of their students, and the larger gendered discourses" could open spaces in their current and future classrooms to better understand the larger gendered institutions in which we all participate (2016, p. 52). Weaver-Hightower (2011) points out places where intervention may disrupt both stereotypes about and biases against teachers; among them, the metacognitive awareness of "gendered stylizations" that may provide opportunities for preservice teachers to more deeply consider alternatives to the "explicit performance" of gender in front of the class (pp. 112-113). Helping students in teacher education programs to recognize their own biases is imperative for developing a teaching force equipped to continue this work with their students" (Engebretson, 2016, p. 52).

Problems of the masculine/feminine subject-object socialization that steer men away and lead those who teach to feel increased suspicion (outlined above in Everitt, 2018) may need to be addressed by larger cultural forces. Cushman's (2012) study is grounded in the movement to attract and retain more male teachers in elementary schools in Sweden, the U.K., and New Zealand. It explores the extent to which men in these countries "considered their teacher education had enhanced their understanding of gender and prepared them to teach in ways that counteracted traditional gender patterns" (p. 776). Similar to the U.S., because of the disparity 


\section{THE NEBRASKA EDUCATOR, VOLUME 6}

between men and women in teacher education programs in the U.K. and New Zealand, "the journey through teacher education can be a lonely and challenging experience" for men (Cushman, 2012, p. 787). In Sweden, however, the experience was very different. Cushman argues that this is a product of cultural distinctions resulting from more than 50 years of political emphasis on gender equality where challenging gender stereotypes has become pervasive. Teacher education courses there tend to complement this agenda, and their immersion in a culture prioritizing gender equality means, perhaps, that less emphasis is necessary (Cushman, 2012, p. 787). Cushman's findings indicate that, minus such a nationwide phenomenon, increasing the emphasis on gender equality in teacher education programs may not be enough without a broader cultural push (Cushman, 2012, p. 788).

Vavrus (2008) argues for "queering" the teacher education curriculum, deconstructing and interrogating "normative dichotomous sexualities" (p. 384) as a way for prospective teachers to examine the formative experiences that give voice to their own gender and sexual identities. Such queering helps education students, the vast majority of whom are cisgender and heterosexual, "to examine how their own sense of sexuality and gender identification is imbued with various degrees of compulsory heterosexuality and the resulting problematic effects this can have for all young people at various stages of identity development” (Vavrus, 2008, p. 384). Vavrus (2008) argues for the use of critical texts with an emphasis on student autoethnographic writing to emphasize reflection on issues related to sex, sexuality, and gender "intended to propel the teacher education student into critical insights as to how their own subjective meanings connect to wider social phenomena and how emancipatory action is possible" (p. 386).

Like Vavrus (2008), Warren (2013), emphasizes reflection in his recommendations for questioning cultural and institutional assumptions. Writing of his experience as a man of color in 


\section{THE NEBRASKA EDUCATOR, VOLUME 6}

a teacher education program, he discusses the misalignment of many programs with the realities of dealing with the intersectional marginalization faced in poor classrooms. Teaching demands awareness and innate in that is reflection, an understanding of "how to critique his or her own practice in such a way that children stay central to the work" (Warren, 2013, p. 173), even as the administrative culture of school reform tries to put instruction at the center. "Technical skills such as how to write a lesson plan mean very little to a child labeled by the institution as 'at-risk' and uneducable. My training didn't account for the uniqueness of Black, poor, or urban youth” (Warren, 2013, p. 173). Preservice teachers must have the awareness and the tools to educate, a process that extends far beyond methods and instructional strategies.

Additionally, consistent multicultural and multilayered coursework must be woven into the discussion of gender norms in teaching programs. Jones' (2011) study found that both overt and institutional racism "wreak havoc on the success of the preservice African American male social studies teacher" (p. 116). He recommended implementing a number of steps to mitigate this oppression, including requiring all faculty in teacher education programs "to be well-versed in and teach from culturally relevant pedagogies and practices that best support students of color" to be sure that all teacher education students, regardless of race, but particularly students of color, "feel empowered to respond to racist presentations without fear of repercussions" (p. 117). To claim this agency, this "voice," as Jones calls it, could help the African American preservice teacher "fight racism whenever and wherever it happens" (p. 117), and to be able to take that attitude into a classroom of their own.

Powers and Duffy (2016) built on the premise that "teacher education requires that preservice teachers do more than just read about anti-oppressive education, [they must] engage in ways that situate them within the shifting dynamic of teaching and learning." (p. 63) In this case, 


\section{THE NEBRASKA EDUCATOR, VOLUME 6}

the physical interaction of theatre became a vehicle for pursuing empathy. Powers and Duffy's (2016) study examines whether Augusto Boal's theatre of the oppressed could create openings for preservice teachers "to... recognize subordinated positionalities in themselves and 'the other'... to interrupt the cycle of socialization" (p. 63). Participants (pre-service teachers) walked away with a sometimes profound and deepened sense of the complex web of possible identities and how various intersectional factors contribute to inequalities. While there were limits to the extent to which this sample of largely White, middle-class women could internalize an understanding of intersectional contributions to oppression through a few performance activities, the data indicate that in subsequent classroom interactions there was better empathetic connection to lived experience.

Beyond activities, classes, or general recommendations, there have been systematic changes made to address these issues. Kearns, Mitten-Kukner, and Tompkins (2017) explain the “Positive Space Program” at Queen's University in Canada providing LGBTQ+ education for preservice teachers. The results of their study show the promise of the program for helping to develop educators "who can interrupt the gender binary [and] allow spaces for diversity of genders to be seen" (2017, p. 22). Developing such awareness in teachers and the willingness to act on that awareness, according to Kearns, Mitten-Kukner, and Tompkins (2017) can help to foster "the highly nuanced and complicated school, gender, and social justice advocacy discussions that embody social change" (p. 22). Rosiek, Schmitke, and Herffernan (2017) have worked to implement such change at the University of Oregon. They spent years shifting the focus of teacher education programs to emphasize issues of LGBTQ+ and gender justice, despite the silence that so often permeates such programs driven by "patriarchal and heteronormative ideologies [that] operate to minimize recognition of the seriousness of these issues" (p. 14). As 
THE NEBRASKA EDUCATOR, VOLUME 6

faculty members, they reinvented their teacher education program to deeply and consistently examine issues of gender justice, illustrating "the vital importance of breaking such silences in professional and educational settings" (2017, p. 14). Rosiek, Schmitke, and Herffernan's (2017) description of the process that led to that change offers much to faculty and administrators who are working to reimagine their own programs.

Consistent among these arguments for change is ongoing engagement with notions of "difference" in order to shift a largely White, female, cisgender paradigm to one that includes regular inclusion of multiple students' and teachers' voices. Such programs clearly have advantages for disrupting gender binaries and broadening the cultural and institutional understanding of what it looks like to teach, but while curriculum and reflection are essential elements for teacher preparation, they are just one step toward cultivating a vibrant and diverse cohort of students and faculty.

\section{Summary and Conclusions}

Despite years of steps taken to address the gender and cultural divides between students and their teachers, the gulf remains glaring and the consequences severe. The result has been the continued perpetuation of gender, class, and racial stereotypes in classrooms, which only further marginalizes those who have traditionally felt unwelcome or uncomfortable. When students spend their educational lifetimes being instructed by teachers who don't look like them, think like them, or interact like they do, the implicit message is that only others are supposed to thrive in the classroom, and only others are destined to teach. Creating a more welcoming environment for traditionally marginalized students by increasing the diversity of embodiment and lived experience among teachers with whom they interact every day would play a crucial role in addressing long-standing structural inequalities that continue to threaten our society. 


\section{THE NEBRASKA EDUCATOR, VOLUME 6}

While much work has been done to investigate gender and race in K-12 schools and teacher education programs in hopes of addressing these divides, there is room for deeper, more sustained looks at intersectional groups of preservice teachers. As Weaver-Hightower (2011) wrote, "if teacher educators and policymakers are truly interested in an increased — and hopefully increasing racially, socioeconomically, and sexually diverse-pool of male teachers, the voices of those training to be teachers must be considered" (pp. 98-99). In the spirit of narrative work done by Jones (2011), Miller and Hidehiro (2005), Sharp-Hoskins and Robillard (2012), Heinrich (2012), and Bortolome (2016), a more sustained longitudinal look at men from a variety of backgrounds in a teacher education program could capture, in Frie, Berweger, and Buschor's (2017) words, a "better understand[ing] of the process leading to the decision for or against teaching” (p. 546). Longitudinal narrative work would provide a more intimate and sustained understanding of the social and cultural positioning that leads young men to the decision to teach and their experiences in a teacher education program. Observing and interacting in depth with these men for a period of several semesters could yield important insights into intersectionality in schools and teacher education that could help open the doors for more students to follow. The more teacher preparation programs understand about the experiences of those who come from communities that typically do not produce teachers, the better positioned they will be to invite students from diverse backgrounds into their programs and effectively prepare them to be conscientious teachers once they get there.

An increase in the number and variety of men who teach, particularly in the humanities, could help to establish new norms for appropriately masculine behavior. Kimmel's (2008) findings that "guys hear the voices of the men in their lives - fathers, coaches, brothers, grandfathers, uncles, priests - to inform their ideas of masculinity" (p. 55) could in fact become 


\section{THE NEBRASKA EDUCATOR, VOLUME 6}

the conduit that leads young men from diverse backgrounds into classrooms of their own. Teachers have the rare opportunity to support the empowerment of all of their students, but even by inadvertently perpetuating cultural prejudices, they have just as much power to stifle it. All teacher education programs must strive, not only to attract and retain future educators from a variety of backgrounds, but to better understand them when they get there and make sure they understand how powerful their presence can be for shaping the lives of their students. 
THE NEBRASKA EDUCATOR, VOLUME 6

\section{References}

Abelson, M. (2019). Men in Place: Trans Masculiniy, Race, and Sexuality in America. Minneapolis, Mn.: University of Minnesota Press.

Ahmad, F.Z., and Boser, U. (2014). “America’s Leaky Pipeline for Teachers of Color: Getting More Teachers of Color into the Classroom." Center for American Progress. Retrieved at Americanprogress.org

American Psychological Association (2015). "Measuring Socioeconomic Status and Subjective Social Status.” Retrieved from https://www.apa.org/pi/ses/resources/class/measuringstatus.

Bartolome, S. J. (2016). “Melanie's Story: A Narrative Account of a Transgender Music Educator's Journey.” Bulletin of the Council for Research in Music Education. No. 207207 (Winter/Spring 2016), p. 25-47.

Benton, T. (2007). “A Class Traitor in Academe." Chronicle of Higher Education. 54(11), p 7071.

Bower-Phipps, L., Homa, T.D., Albaladejo, C., Mello Johnson, A., Cruz, M.C. (2013).

“Connecting with the 'Other' Side of Us: A Cooperative Inquiry by Self-Identified Minorities in a Teacher Preparation Program. Teacher Education Quarterly (Spring 2013), p. 29-51

Connell, R.W. (2005). Masculinities. (2 ${ }^{\text {nd }}$ Edition). Berkeley, CA: University of California Press.

Crenshaw, K. (1991). "Mapping the Margins: Intersectionality, Identity Politics, and Violence against Women of Color.” The Stanford Law Review. 43(6), p. 1241-1299.

Davison, K.G. and Nelson, B.G. (2011) "Men and Teaching: Good Intentions and Productive Tensions." The Journal of Men's Studies. 19(2), 91-96. 
THE NEBRASKA EDUCATOR, VOLUME 6

Dee, T. (2005). “A Teacher Like Me: Does Race, Ethnicity, or Gender Matter?” American Economic Review. 95(2), p. 158-165.

Dee, T. (2007). "Teachers and the Gender Gaps in Student Achievement." The Journal of Human Resources. 42(3), p. 528-554.

Dowd, N. (2010) The Man Question: Male Subordination and Privilege. New York: NYU Press.

Dolton, P., Marcenaro, O., De Vries, R., \& She, P.W. (2018) “Global Teacher Status Index 2018." Varkey Foundation. Retrieved at https://www.varkeyfoundation.org/media/4867/gts-index-13-11-2018.pdf

Dykins Callahan, S. (2008). “Academic Outings.” Symbolic Interaction. 31(4), p. 351-375.

Ferrell, W. and Gray, J. (2018). The Boy Crisis: Why Our Boys are Struggling and What We Can Do About It. Dallas, TX: Benbella Books.

Fischman, G. (2000). Imagining Teachers: Rethinking Gender Dynamics in Teacher Education. New York: Rowman and Littlefield Publishers.

Francis, B. (2008). “Teaching Manfully? Exploring Gendered Subjectivities and Power Via Analysis of Men Teachers' Gender Performance." Gender and Education. 20(2), p. 109122.

Frie, A.K., Berweger, S., and Buschor, C.B. (2017). "Men Considering (and choosing) teaching as a career: what accounts for their decision to become a teacher?" European Journal of Teacher Education. Vol 40, No. 4, p. 535-549

Gosse, D. (2011). "Race, Sexual Orientation, Culture, and Male Teachers as Role Models: 'Will Any Teacher Do as Long as They Are Good?"” The Journal of Men's Studies. 19(2), p. 116-137. 
THE NEBRASKA EDUCATOR, VOLUME 6

Haase, M. (2008). "'I don't do the mothering role that lots of female teachers do:' male teachers, gender, power, and social organization.” In Coffee, A. and James, D. (Eds) (2014) Masculinity and Education. London: Routledge.

Hammerness, K., \& Reininger, M. (2008). Who goes into early-entry programs? In P. Grossman \& S. Loeb (Eds.), Alternative Routes to Teaching: Mapping the New Landscape of teacher education (pp. 31-64). Cambridge, MA: Harvard Education Press.

Hansen, M., Lovesque, E.M.,Valant, J. \& Quintero, D. (2018). The 2018 Brown Center Report on American Education. "Understanding the Social Studies Teacher Workforce." Retrieved October $12^{\text {th }}, 2020$. https://www.brookings.edu/research/2018-brown-centerreport-on-american-education-understanding-the-social-studies-teacher-workforce/

Heinrich, J. (2012). "The Making of Masculinities: Fighting the Forces of Hierarchy and Hegemony in the High School Setting.” The High School Journal. 96(2) p. 101-115.

Ingersoll, R.M., Merrill, E., Stuckey, D., \& Collins, G. (2018). “Seven Trends: The Transformation of the Teaching Force - October 2018." CPRE Research Reports. Retrieved from https://repository.upenn.edu/cpre_researchreports/108

Johnson, S. P., Porter, G., \& Nelson, B. G. (2008, Winter). The status of male teachers in public education today (Education Policy Brief Vol. 6, No. 4, pp. 1-12). Bloomington: Center for Evaluation \& Education Policy, Indiana University.

Jones, S. (2011). “A Long Road to Travel: Narratives of African American Male Preservice Educators' Journeys Through a Graduate Teacher Education Program.” (Unpublished doctoral dissertation). Georgia State University, Atlanta, Ga. 
THE NEBRASKA EDUCATOR, VOLUME 6

Kahn, Jack S., Brett, Benjamin, L., and Holmes, Jessica R. “Concerns with Academic Motivation in Men's Higher Education: An Exploratory Investigation of the Role of Masculinity. The Journal of Men's Studies. Vol. 19. No. 1, Winter 2011, p 65 - 82.

Kearns, L., Mitton-Kukner, J., and Tompkins, J. (2017). “Transphbia and Cisgender Privilege: Pre-Service Teachers Recognizing and Challenging Gender Rigidity in Schools.” Canadian Journal of Education. 40(1), p. 1-27

Kimmel, M. (1998, 2018). Manhood in America: A Cultural History. New York, NY.: Oxford University Press.

Kimmel, M. (2008, 2018). Guyland: The Perilous World Where Boys Become Men. Understanding the Perilous Years Between 16 and 26. New York, NY.: Harper Collins. Kivel, P. (2009) “The Act-Like-A-Man Box.” Kimmel, M. S. and Messner, M. A. (Ed). Men's Lives (10 ${ }^{\text {th }}$ Edition). (2019). New York, NY: Oxford University Press

Lareau, A. (2011). Unequal Childhoods: Class, Race, and Family Life. Berkeley, Ca: University of California Press.

Lewis, C.W. (2009). "Black Male Teachers' Path to U.S. K-12 Classrooms: Framing the National Discussion." Diversity and Education: Teachers, Teaching, and Teacher Education. (Richard H. Milner, Ed). Springfield, Il: Charles C. Thomas.

Lowenstein, K.L. (2009). “The Work of Multicultural Teacher Education: Reconceptualizing White Teacher Candidates as Learners." Review of Educational Research. 79(1) p. 163196.

Martino, W. (2001). "Dickheads, Wuses, and Faggots: Addressing issues of masculinity and homophobia in the critical literacy classroom.” In B. Comber \& A. Simpson (Eds.), 
THE NEBRASKA EDUCATOR, VOLUME 6

Negotiating critical literacies in classrooms (pp. 191-210). Mahwah, NJ: Lawrence Ehrlbaum Associates.

Martino, W. and Rezai-Rashti, G.M. (2010). “Male Teacher Shortage: Black Teachers’ Perspectives." Gender and Education. 22(3), p 247-262.

Miller, R. (2005). Teaching at the End of the World. Pittsburgh, Pa: University of Pittsburgh Press.

Miller, P. C. and Hidehiro, E. (2005). "Journey to Becoming a Teacher: The Experience of Students of Color.” Multicultural Education. 3(1) Oct - Dec 2005, p. 2 - 9.

Mills, M. (2004). “Male Teachers, Homophobia, Misogyny and Teacher Education.” Teaching Education. 15(1), 27-39.

Mintz, S. (2019). “The Other Gender Gap.” Inside Higher Ed. Blog: Higher Ed Gamma, August $4^{\text {th }}, 2019$. Accessed August 31, 2020. https://www.insidehighered.com/blogs/higher-edgamma/other-gender-gap.

Pascoe, C. J. (2011). “Guys Are Just Homophobic: Rethinking Adolescent Homophobia and Heterosexuality.” Kimmel, M. S. and Messner, M. A. (Eds). Men's Lives (10 ${ }^{\text {th }}$ Edition). (2019). New York, NY: Oxford University Press.

Pascoe, C.J. (2007). Dude, You're A Fag: Masculinities and Sexuality in High School. Berkeley, CA: University of California Press.

Perry, Mark J. (2019). “Chart of the Day: Female Shares of BA Degrees by Major, 1971 2017." American Enterprise Institute. Accessed July 27 $7^{\text {th }}, 2021$. https://www.aei.org/carpe-diem/chart-of-the-day-female-shares-of-ba-degrees-by-major1971-to-2017/ 
THE NEBRASKA EDUCATOR, VOLUME 6

Powers, B. and Duffy, P.B. (2016). “Making Invisible Intersectionality Visible through Theatre of the Oppressed in Education." The Journal of Teacher Education. 67(1), p. 61-73.

Sanders, J. (2002). "Something is Missing from Teacher Education: Attention to Two Genders." Phi Delta Kappan, 84(3), p 241-244.

Sandles, D. (2020). "Using Critical Race Theory to Explore the Black Men Teacher Shortage." The Journey of Negro Education. 89(1), p. 67-81.

Sexton, P.C. (1969). The Feminzed Male: Classrooms, White Collars and the Decline of Manliness. New York, NY: Vintage Books.

Sharp-Hoskins, K. and Robillard, A. (2012). "Narrating the 'Good Teacher' in Rhetoric and Composition: Ideology, Affect, Complicity.” JAC. 32(1/2), pp. 305-336.

Skelton, C. (2007). “Gender, Policy, and Initial Education.” Gender in Education. 19(6), p. 677690.

Snyder, T.D. (Ed). (1993). 120 Years of American Education: A Statistical Portrait. Published by the Center for Educational Statistics. Accessed at https://nces.ed.gov/pubs93/93442.pdf

Stillman, J., Struthers Ahmed, K., Luciano Beltramo, J., Catañeda-Flores, E., Garza, V.G., \& Pyo, M. (2019) "From the ground up: cultivating teacher educator knowledge from the situated knowledges of emerging, asset-oriented teacher educators." Asia-Pacific Journal of Teacher Education. 47(3), 265-285.

Tucker, Stephen. (2015). “Three Men and a Maybe: Identity and Privilege in Preservice Elementary School Teachers.” Journal of Men's Studies. 23(1), p. 3-20.

U.S. Department of Education (2021). Report on the Condition of Education 2021. Accessed at https://nces.ed.gov/pubs2021/2021144.pdf 
THE NEBRASKA EDUCATOR, VOLUME 6

Villegas, A.M. (2008). “Diversity and Teacher Education.” M. Cochran-Smith, S. Freiman Nemser, \& D.J. McIntyre (eds.). Handbook on Research in Teacher Eduduation: Enduring Questions in Changing Contexts ( $3^{\text {rd }}$ Edition). Philadelphia, PA: Routledge.

Villegas, A.M., \& Irvine, J.J. (2010). "Diversifying the Teaching Force: An Examination of Major Arguments." The Urban Review. 42, 175-192

Waite, S. (2017). Teaching Queer: radical possibilities for writing and knowing. Pittsburg, Pa: University of Pittsburg Press.

Warren, C. A. (2013). Being black, being male, and choosing to teach in the 21 st century: Understanding my role, embracing my call. In C. W. Lewis \& I. A. Toldson (Eds.), Black male teachers: Diversifying the United States' teacher workforce (pp. 167-182). Bingley: Emerald Group Publishing Limited.

Weaver-Hightower, M. (2011). "Male Preservice Teachers and Discouragement from Teaching." The Journal of Men's Studies. 19(2) pp. 97-115.

Young, V. A., (2007). Just Your Average Nigga Performing Race and Masculinity. Detroit, Mi: Wayne State University Press.

Zeichner, K. (2020). "Preparing Teachers as Democratic Professionals.” Action in Teacher Education. 42(1). 38-48. DOI: 10.1080/01626620.2019.1700847 